CARPATHIAN JOURNAL OF FOOD SCIENCE AND TECHNOLOGY

journal homepage: http://chimie-biologie.ubm.ro/carpathian_journal/index.html

\title{
STANDARDIZATION, CHARACTERIZATION AND STORAGE STABILITY OF CURRY LEAF CHUTNEY
}

\author{
Renu Khedkar ${ }^{1 *}$, Pratima Shastri ${ }^{2}$, Amarinder Singh Bawa ${ }^{3}$, \\ ${ }^{1,3}$ Amity Institute of Food Technology, AUUP, Noida, India; \\ ${ }^{2}$ Department of Food Technology, LIT, Nagpur, India \\ *rdkhedkar@amity.edu
}

https://doi.org/10.34302/crpjfst/2019.11.3.13

\begin{tabular}{ll}
\hline Article history: & ABSTRACT \\
Received: & Curry leaf (Murraya koenigii) or 'Kadipatta' is an important leaf-spice used \\
28 July 2018 & in curries, pickles and chutneys as a natural flavoring. Curry leaf is a rich \\
Accepted: & source of fibers, minerals and vitamins such as calcium, iron, phosphorus \\
10 August 2019 & and carotene, niacin, vitamin $\mathrm{B}_{2}$ and vitamin C. The present study aimed to \\
standardize the Curry leaf chutney, assess its nutritional value and study the & storage stability of the product in a suitable packaging material under \\
Keywords: & ambient temperature $\left(15-35^{\circ} \mathrm{C}\right)$ conditions for a period of 90 days. \\
Food adjunct; & Preparation of Curry leaf chutney was standardized using roasted Bengal \\
Sorption studies; & gram $(40 \%)$, Black gram $(20 \%)$, dried curry leaves $(10 \%)$ roasted in $10 \%$ oil \\
Storage stability; & and spice mix $(30 \%)$. The product had a low moisture content of $2.57 \%$, \\
TBA; & was rich in protein $(20.01 \%)$ and carbohydrates $(56.99 \%)$. Sorption studies \\
Colour analysis; & indicated that the critical moisture content for the product was found to be \\
Microbiological analysis & $9.79 \%$, which corresponded to $68 \%$ RH indicating non- hygroscopic nature. \\
& Storage studies conducted in PET/Metallized polyester/Polythene pouches \\
under ambient temperature $\left(15-35^{\circ} \mathrm{C}\right)$ conditions for a period of 90 days \\
indicted that the overall acceptability scores for product ranged from 8.7 \\
(excellent) to 8.2 (very good), the tintometer colour units of Red varied from \\
3.3 to 3.8 units while units for yellow and blue constant. TBA values for the \\
product also remained low indicting no rancidity development. Microbial \\
analysis showed that an increase in the rate of growth of ACC was observed \\
after 75 days of storage in PET/Metpoly /PE samples.
\end{tabular}

\section{Introduction}

The role of Indian spices in preventive and therapeutic medicine has been reported in ancient literature (Tapsell, 2006). Curry leaf (Murraya koenigii) or 'Kadipatta' is an important leaf-spice used in curries, pickles and chutneys as a natural flavoring (Rao et al.,2004; Khedkar,2015). The leaves are slightly bitter, cooling and weakly acidic in taste. The presence of volatile oils give it the distinct aroma. The leaves retain their colour and flavor even after drying, and so are utilized in fresh and dried form (Ramalakshmi et al., 2000). The tree is found in tropical and sub- tropical regions from Sri Lanka, India, China, Malaysia, Australia, and in the Pacific from the Mariana Islands to
Vanatau and New Caledonia (Smith, 1985). The tree is native to India, Bangladesh, Sri Lanka \& Andaman Islands which later spread to other parts of the world with Indian immigrants. It is widely grown almost all over India up to an altitude of $1650 \mathrm{~m}$. It is cultivated for its aromatic leaves and is commonly found in home gardens of South India (Joseph and Peter, 1985).

Since thousands of years, the classical Indian, Greek and Latin literature has reported the health benefits of curry leaf (Mathias, 1994). Curry leaves are known worldwide for their excellent antibacterial, antifungal, antioxidant properties, pesticidal and nutraceutical potential (Deshmukh et al.,1986; Pathak et al.,1997; Khedkar, 2015). Curry leaves contain bioactive 
compounds having functional properties e.g. oxalic acid, vitamin A, koenigin, bicyclomahanimbicine, cyclomahanimbine, murrayastine, coumarine, koenidine and pypayafolinecarbazole impart nutraceutical potential to the leaves. Curry leaf is a rich source of fibers, minerals and vitamins such as calcium, iron, phosphorus and carotene, niacin, vitamin $\mathrm{B}_{2}$ and vitamin $\mathrm{C}$ (Ganesan et al., 2013).

The leaves are a good source of vitamin A and calcium but due to the presence of high concentrations of oxalic acid, its nutritional availability is affected (The Wealth of India,2001). The TDF (Total dietary fiber), IDF (Insoluble dietary fiber) and SDF (Soluble dietary fiber) of curry leaves has been reported to be $16.3 \%, 13.4 \%$ and $2.9 \%$ (Punna and Rao,2004).

Traditional food adjuncts such as chutneys, pickles, papad are widely consumed and are an integral of Indian thali (lunch/dinner) since ages. Many studies have been conducted on the standardization and characterization of such food adjuncts. Khedkar et al., (2016) studied the standardization and shelf stability of a pulse based chutney powder, Metkut. Satyanarayan et al., (2013) prepared and studied the storage of flaxseed chutney. Rao et al., (2008) standardized raw mango chutney powder. Although consumed in small amount, these food adjuncts provide excellent source of nutrition along with enhancement in salivation and aiding the digestion process (Shastri, 2006). Traditionally prepared in the households, these dry and wet chutneys have a short shelf life and are available only during the season. Increasing urbanization and women work force and rising purchasing power in cities has led to a need to supply these adjuncts round the year ( Khedkar et al., 2016).

This study was undertaken to standardize the formulation as well as process parameters ,evaluation of nutritive quality and storage stability of the Curry leaf chutney.

\section{Materials and Methods}

\subsection{Materials}

Major ingredients used in the preparation of curry leaf chutney were fresh curry leaves
(Murraya koenigii), dehulled - split bengal gram (Cicer arietinum), dehulled - split black gram (Phaseolus mungo), whereas the minor ingredients were sesame seeds (Sesamum indicum), sugar, salt, dry mango powder (Mangifera indica), cumin seeds (Cuminum cyminum) and red chili powder (Capsicum annum). All ingredients were procured from the local market at Noida, India and were cleaned of any dirt or physical impurities.

\subsection{Standardization of formulation of Curry leaf chutney}

Fresh curry leaves were cleaned, washed and dried in a tray dryer at $45 \pm 2^{\circ} \mathrm{C}$ till constant weight. Dehulled -split Bengal gram, dehulled split black gram, sesame seeds and cumin seeds were measured, roasted in an open pan till brown and the roasted aroma developed. The dried curry leaves were measured and roasted in $10 \%$ (of the total quantity of chutney) of refined sunflower oil till crisp. The roasting temperature was kept constant at $150^{\circ} \mathrm{C}$. The temperature was regulated with infrared thermometer (Mextech, India).

\subsubsection{Standardization of curry leaves and spice mix in Curry leaf chutney}

A spice mix was prepared by weighing the sugar, salt, roasted sesame seeds, roasted cumin seeds, red chili powder and dry mango powder, grinding in a mixer grinder (Inalsa, India) and sieving it through BS30 $(500 \mu)$ mesh sieve to obtain a uniform size powder. The spice mix was standardized through various trials conducted using the different levels of sugar (5$10 \%)$, Salt (2-5\%), roasted sesame seeds (8-12\% ), roasted cumin seeds (2-5\%), red chili powder (1-4\%) and dry mango powder (2-5\%).

For the standardization of levels of dried curry leaves and the spice mix in the formulation of curry leaves chutney, three sample were prepared using dried curry leaves and spice mix as CLC1(5:35), CLC 2 (10:30) and CLC3 $(15: 25)$ as shown in Table 2. The levels of bengal gram and black gram were kept constant at $50 \%$ and $10 \%$ respectively. The samples were subjected to sensory evaluation by preference 
ranking test (Meilgaard et al.,1999) by a semitrained panel consisting of 10 judges to evaluate the overall quality of the products by panelists who were earlier familiarized with the quality attributes of the product. The most preferred sample was ranked 1 , next ranked 2 and so on.

Table 1. Composition of spice mix in Curry leaf chutney

\begin{tabular}{|c|c|}
\hline Ingredients & Composition (\% by weight) \\
\hline Sesame seeds & 40 \\
\hline Sugar & 20 \\
\hline Cumin seeds & 13.33 \\
\hline Dry mango powder & 10 \\
\hline Salt & 13.33 \\
\hline Red chili powder & 3.34 \\
\hline
\end{tabular}

Table 2. Standardization of dried curry leaves and spice mix in Curry leaf chutney

\begin{tabular}{|l|c|c|c|}
\hline \multicolumn{1}{|c|}{ Ingredients (\%) } & CLC1 & CLC 2 & CLC3 \\
\hline $\begin{array}{l}\text { Dried curry } \\
\text { leaves }\end{array}$ & 5 & 10 & 15 \\
\hline Spice mix & 35 & 30 & 25 \\
\hline Bengal gram & 50 & 50 & 50 \\
\hline Black gram & 10 & 10 & 10 \\
\hline
\end{tabular}

2.2.2.Standardization of major ingredients; Bengal gram and Black gram

Composition of Bengal gram and black gram, the major ingredients in the curry leaf chutney recipe was optimized by preparing 3 different samples of curry leaf chutney A, B and
$\mathrm{C}$ using the levels of Bengal gram at 50\%, $40 \%$ and $30 \%$ and Black gram at $10 \%, 20 \%$ and $30 \%$. The dried curry leaves and the standardized spice mix was maintained at $10 \%$ and $30 \%$ respectively (Table 3 ).

Table 3. Standardization of levels of Bengal gram and black gram in Curry leaf chutney

\begin{tabular}{|l|c|c|c|}
\hline Ingredients (\%) & Sample A & Sample B & Sample C \\
\hline Bengal gram & 50 & 40 & 30 \\
\hline Black gram & 10 & 20 & 30 \\
\hline Dried curry leaves & 10 & 10 & 10 \\
\hline Spice mix & 30 & 30 & 30 \\
\hline
\end{tabular}

The formulation of curry leaf chutney was standardized after conducting sensory evaluation on product from the trials. Sensory evaluation was conducted by a semi-trained panel consisting of 10 judges using 9- point hedonic scale where $1=$ dislike extremely and $9=$ like extremely (Amerine et al., 1965). The panelists were earlier made to acquaint with the quality parameters using commercial product.

\subsection{Proximate evaluation of Curry leaf chutney}

The standardized samples of Curry leaf chutney were analyzed in triplicate for proximate composition. Moisture, crude fat, total protein, crude fiber and ash contents were estimated using standard methods (Ranganna, 2001). Carbohydrates were estimated by the difference method. Energy values were calculated by the standard method of summing 
up the values of Total carbohydrates, crude protein and crude fat obtained and multiplying the quantity of carbohydrate and protein per $100 \mathrm{~g}$ by $4 \mathrm{kcal}$ and that of fat per $100 \mathrm{~g}$ by $9 \mathrm{kcal}$ respectively (Atwater and Benedict, 1902).

\subsection{Sorption studies}

Moisture sorption studies were conducted on the standardized samples of Curry leaf chutney by keeping $5 \mathrm{~g}$ of each of the sample in a separate desiccators maintained at different relative humidities e.g.10\%, 30\%, 40\%, 50\%, $60 \%, 70 \%$ and $90 \%$, using varying normality sulphuric acid solutions (Landrock and Proctor,1951) at $25^{\circ}$ C.Sample weights were noted at regular intervals of one day till there was no further loss or gain in weight. Adverse changes like softness, sogginess, discoloration and mold growth were also noted from time to time. Sorption isotherm was plotted on graph. Critical moisture content and equilibrium moisture content were determined from the sorption isotherm.

\subsection{Storage stability studies}

The standardized samples of curry leaf chutney were packaged in PET/Metallized polyester/ PE $(12 \mu / 12 \mu / 70 \mu)$ laminated pouches of size $10 \mathrm{~cm} \times 10 \mathrm{~cm}$, heat sealed with heat sealing machine for conducting the storage/shelf stability studies. The packaged samples were subjected to storage studies under ambient $\left(15-35^{\circ} \mathrm{C}\right)$ storage conditions for 90 days. The storage studies included sensory evaluation using hedonic testing (Amerine et al.,1965) , rancidity development using TBA test, colour units measurement using Lovibond Tintometer model E (Ranganna, 2001) and microbiological evaluation (BAM, 2001).

\subsection{Statistical analysis}

The data were expressed as mean \pm S.D. Statistical analysis was carried out with SPSS version 21.0 using one-way ANOVA followed by Tukey's post hoc test for significance ( $\mathrm{p} \leq$ $0.05)$.

\section{Results \& Discussion}

\subsection{Standardization of formultion of Curry leaf chutney \\ 3.1.1. Standardization of curry leaves and spice mix in Curry leaf chutney}

The composition of the spice mix is given in Table 1. The composition of dried curry leaves $\&$ spice mix in the preparation of curry leaf chutney was standardized based on the results of sensory evaluation by preference test shown in Table 4. The overall quality of sample CLC2 with $10 \%$ dried curry leaves, $30 \%$ spice mix, $50 \%$ Bengal gram and $10 \%$ black gram was most preferred with best score of 1.4, followed by CLC3 (2.1) and CLC1(2.5) respectively. It was noted that the addition of $15 \%$ dried curry leaves resulted in darkening of colour as well as a bitter after taste of curry leaves. The bitterness may be due to the presence of flavor compounds pinene, sabinene, caryophyllene, cardinol and cadinene in curry leaves (Singh et al., 2014). A balanced proportion of curry leaves, spice mix and pulses gave an acceptable taste, body, flavour and colour.

\subsubsection{Standardization of levels of pulses in the recipe of Curry leaf chutney}

The sensory scores for the selection of composition of pulses, bengal gram and black gram in the formulation of curry leaf chutney has been shown in Fig.1 and Table 5. In the standardization of composition of pulses, the major ingredients, out of the three combinations, sample B scored over sample A \& C in the sensory evaluation. Sample B with bengal gram $(40 \%)$, black gram $(20 \%)$, dried curry leaves $(10 \%)$, spice mix $(30 \%)$ had the characteristic colour, flavour and texture. Addition of $60 \%$ bengal gram and $10 \%$ black gram resulted in the change of colour from green to yellow with a gritty texture, whereas at $30 \%$ level of bengal gram and black gram, the colour of curry leaf chutney was pale green but with a fine texture. The composition of standardized curry leaf chutney has been given in Table 6 
Table 4. Preference ranking scores for standardization of dried curry leaves and spice mix in Curry leaf chutney $(n=10)$

\begin{tabular}{|l|l|l|l|}
\hline Rank/ Sample & CLC1 & CLC2 & CLC3 \\
\hline Mean rank \pm s.d. & $2.5 \pm 0.85$ & $1.4 \pm 0.7$ & $2.1 \pm 0.57$ \\
\hline Remarks & $\begin{array}{l}\text { More spicy, less } \\
\text { flavour of curry } \\
\text { leaves, dull brown } \\
\text { colour }\end{array}$ & $\begin{array}{l}\text { Good flavour of curry } \\
\text { leaves and spices, } \\
\text { bright green colour }\end{array}$ & $\begin{array}{l}\text { Strong aroma and } \\
\text { bitter aftertaste of } \\
\text { curry leaves, dark } \\
\text { green colour }\end{array}$ \\
\hline
\end{tabular}

Values are average \pm S.D.

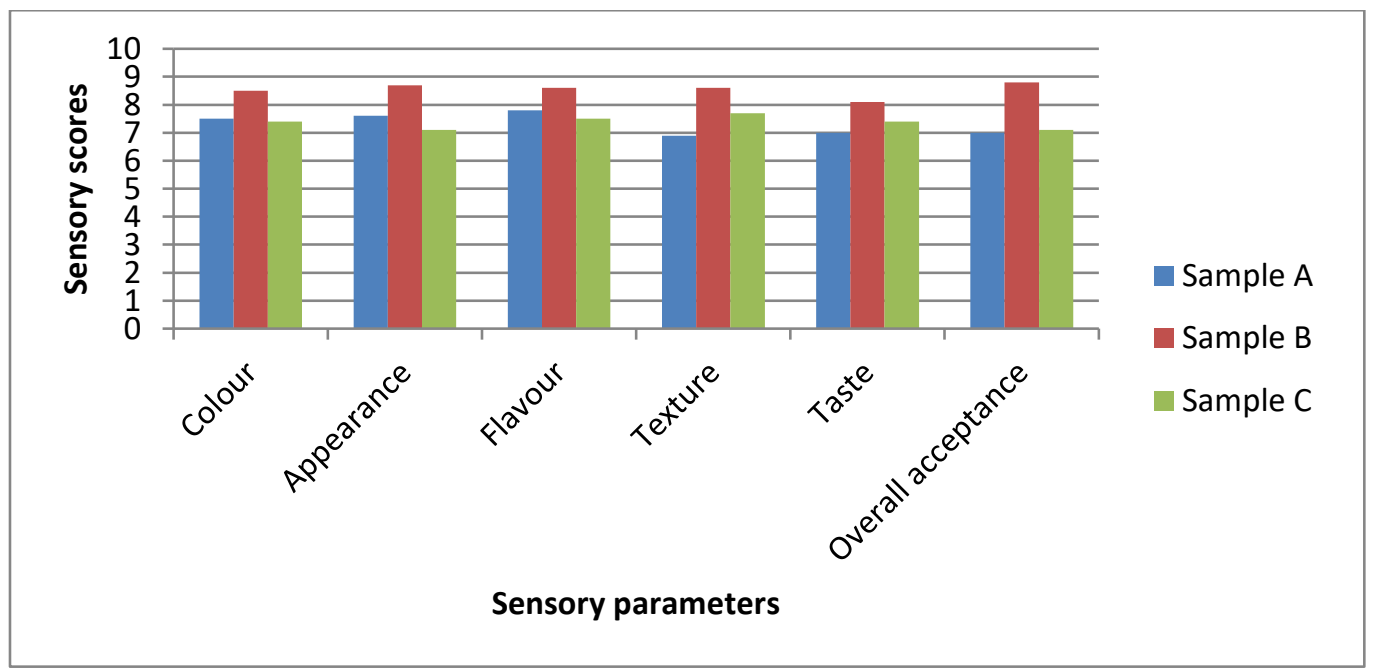

Figure 1. Sensory scores for standardization of levels of pulses in Curry leaf chutney

Table 5. Sensory scores for selection of levels of Bengal gram and black gram in Curry leaf chutney

\begin{tabular}{|c|c|c|c|}
\hline \multicolumn{5}{|c|}{$(\mathrm{n}=10)$} & $\mathbf{B}$ & $\mathbf{C}$ \\
\hline Parameter/sample & $\mathbf{A}$ & $8.5 \pm 0.71$ & $7.4 \pm 0.97$ \\
\hline Colour & $7.5 \pm 0.71$ & $8.7 \pm 0.48$ & $7.1 \pm 0.88$ \\
\hline Appearance & $7.6 \pm 0.70$ & $8.6 \pm 0.7$ & $7.5 \pm 0.71$ \\
\hline Flavour & $7.8 \pm 1.03$ & $8.6 \pm 0.7$ & $7.7 \pm 0.82$ \\
\hline Texture & $6.9 \pm 0.74$ & $8.1 \pm 0.99$ & $7.4 \pm 0.7$ \\
\hline Taste & $7 \pm 0.82$ & $8.8 \pm 0.42$ & $7.1 \pm 0.88$ \\
\hline Overall acceptance & $7.4 \pm 0.70$ & $\begin{array}{c}\text { Colour bright } \\
\text { green, fine texture } \\
\text { fresh aroma }\end{array}$ & $\begin{array}{c}\text { Colour pale green, fine } \\
\text { texture, less aroma }\end{array}$ \\
\hline
\end{tabular}

Values are average \pm S.D. 
Table 6. Composition of standardized Curry leaf chutney

\begin{tabular}{|c|c|}
\hline Ingredients & Composition (\% by weight) \\
\hline Dried curry leaves & 10 \\
\hline Bengal gram & 40 \\
\hline Black gram & 20 \\
\hline Spice mix & 30 \\
\hline
\end{tabular}

Table 7. Proximate composition of Curry leaf chutney (per 100g) $(n=3)$

\begin{tabular}{|c|c|c|}
\hline S.No. & Parameter (g) & Curry leaf chutney \\
\hline 1 & Moisture & $2.57 \pm 0.18$ \\
\hline 2 & Protein (\%N x 6.25) & $20.01 \pm 0.07$ \\
\hline 3 & Crude fat & $14.81 \pm 0.15$ \\
\hline 4 & Crude fiber & $1.99 \pm 0.19$ \\
\hline 5 & Total Ash & $5.61 \pm 0.21$ \\
\hline 6 & Carbohydrates & $56.99 \pm 0.23$ \\
\hline 7 & Energy value (kcal) & 441.29 \\
\hline
\end{tabular}

Values are average \pm S.D. and are expressed on sample basis

Weigh $12 \mathrm{~g}$ cleaned sesame seeds and $4 \mathrm{~g}$ cleaned cumin seeds. Roast at $150^{\circ} \mathrm{C}$ till brown. Add $6 \mathrm{~g}$ sugar, $3 \mathrm{~g}$ dry mango powder, $4 \mathrm{~g}$ salt and $1 \mathrm{~g}$ red chili powder. Grind to get the spice mix

Weigh $40 \mathrm{~g}$ cleaned Bengal gram, 20g cleaned black gram and roast at $150^{\circ} \mathrm{C}$
Wash the curry leaves, remove the leaves from stem and dry in a cabinet drier at $45 \pm 2^{\circ} \mathrm{C}$ till constant weight (7-9\% MCwb).

Take the oil roasted leaves and mix it with spice mix, roasted bengal gram and black gram. Grind to a fine powder.

Take $10 \mathrm{~g}$ dried curry leaves. Shallow fry using $10 \mathrm{ml}$ refined oil at $150^{\circ} \mathrm{C}$ till crisp. 


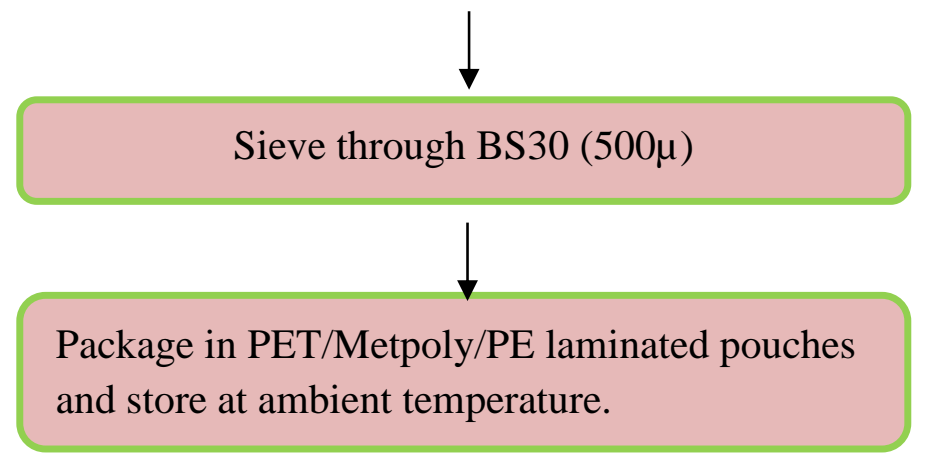

Figure 2. Standardized process for preparation of Curry leaf chutney

\subsection{Proximate analysis of Curry leaf chutney}

As seen from Table 7, the product had a low moisture content of $2.57 \%$, was rich in protein $(20.01 \%)$ and carbohydrates $(56.99 \%)$. The crude fat content was found to be $14.81 \%$, crude fiber $1.99 \%$, total ash $5.61 \%$, and energy value $441.29 \mathrm{kcal}$. Gopalan et al. (2014) reported that bengal gram, black gram, sesame seeds and cumin seeds are a good source of protein $(22.5 \%, 24 \%, 18.3 \%$ and $18.7 \%$ respectively). Sesame seeds are also a good source of fat $(43.3 \%)$. The high protein and fat content can be attributed to the presence of these ingredients in the Curry leaf chutney. Rao et al. (2004) reported the moisture content of $5 \%$, crude protein $16.4 \%$, Crude fat $14.2 \%$, total ash $4.0 \%$, crude fiber $7.0 \%$, carbohydrates $57 \%$, in curry leaf chutney powder prepared from fresh curry leaves fried in $10 \%$ oil, bengal gram, black gram, green gram, coriander seeds, cumin seeds, red chili powder and tamarind pulp.

\subsection{Sorption studies on Curry leaf chutney}

Moisture sorption isotherm was plotted for curry leaf chutney as represented in Fig.3. The product had an initial moisture content of $2.57 \%$, which equilibrated at $48 \% \mathrm{RH}$. The critical moisture content was found to be $9.79 \%$, which corresponded to $68 \% \mathrm{RH}$. It gained moisture quickly at $\mathrm{RH}$ above $72 \%$. The product was found to be non- hygroscopic in nature. The crude fat content of the Curry leaf chutney is $14.81 \%$ indicated suitable packaging material with good light and gas barrier properties . Rao et al. (2004) also examined the moisture sorption isotherm of curry leaf chutney powder. The isotherm obtained was also reported to be sigmoidal, with a S- type curve, which is common for carbohydrate rich foods. Similar type of curves were obtained for instant chutneys prepared from Pudina (mint) and gongura (Hibiscus sp.) as reported by Satyanarayana et al.(2001).

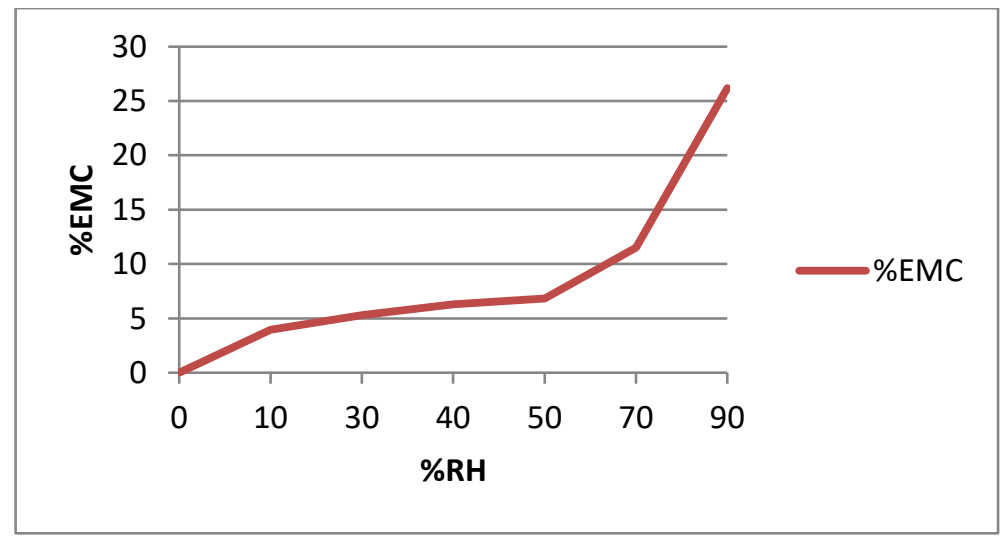

Figure 3. Moisture sorption isotherm for Curry leaf chutney using $\mathrm{H}_{2} \mathrm{SO}_{4}$ solutions of various $\mathrm{RH}$ 
The moisture absorption isotherms for curry leaf chutney at $25^{\circ} \mathrm{C}$ showed three regions, I, II \& III. Region I corresponding to \% RH 0-10 represent monolayer moisture content strongly bound to polar components of the product. Region II, corresponding to \% RH 10-70 is also called as multi molecular phase. In this phase, the slope of the isotherm is small, indicating the changing of multi molecular water to free water. Region III for \% RH above 70 where there is a steep rise in the isotherm, represents the water in the free state and available to chemical and microbial reactions (Kinsella and Fox, 1987).

\subsection{Storage studies on Curry leaf chutney under ambient temperature conditions 3.4.1 Sensory evaluation of Curry leaf chutney stored under ambient temperature $\left(15-35^{\circ} \mathrm{C}\right)$ conditions}

The sensory scores of Curry leaf chutney packed in PET/Metpoly/PE for the storage under ambient temperature conditions are presented in Table 8. The scores for product packed in PET/Metpoly/PE ranged from 8.7 (excellent) to 8.2 (very good) for overall acceptance, 8.8 to 8.1 for flavour, 8.7 to 8.2 for taste, 8.8 to 8.3 for colour respectively. Statistical analysis of the sensory scores for Curry leaf chutney packaged in PET/ Metpoly/PE and stored under ambient temperature conditions for 90 days , was carried out using Tukey's post hoc test . The products packed in PET/Metpoly/PE did not show any significant difference in the sensory scores during the storage period.

3.4.2. Colour measurement of Curry leaf chutney stored at ambient temperature (15$35^{\circ} \mathrm{C}$ ) conditions

The colour changes in curry leaf chutney packaged in PET/Metpoly/PE, during the storage period of 90 days under ambient temperature conditions were measured using Lovibond Tintometer model $\mathrm{E}$ and are presented in Table 9. Tintometer colour units of Yellow (30.0) and Blue (7.0) remained constant during the storage period of 90 days for the product packed in PET/Metpoly/PE. The units of Red varied from 3.3 to 3.8 units indicating a colour change from fresh green to pale green.

Table 8. Sensory scores of Curry leaf chutney during storage under ambient temperature $\left(15-35^{\circ} \mathrm{C}\right)$ conditions for 90 days $(n=10)$

\begin{tabular}{|c|c|c|c|c|c|c|c|}
\hline \multirow{2}{*}{$\begin{array}{l}\text { Parameters/ } \\
\text { storage } \\
\text { days }\end{array}$} & \multicolumn{7}{|c|}{ PET/Metpoly/PE } \\
\hline & O day & 15 day & 30 day & 45 day & 60 day & 75 day & 90 day \\
\hline Colour & $8.8 \pm 0.42^{\mathrm{a}}$ & $8.8 \pm 0.42^{\mathrm{a}}$ & $8.7 \pm 0.48^{a}$ & $8.6 \pm 0.52^{a}$ & $8.5 \pm 0.53^{\mathrm{a}}$ & $8.4 \pm 0.52^{\mathrm{a}}$ & $8.2 \pm 0.42^{\mathrm{a}}$ \\
\hline Appearance & $8.7 \pm 0.48^{a}$ & $8.7 \pm 0.48^{\text {a }}$ & $8.5 \pm 0.71^{\mathrm{a}}$ & $8.4 \pm 0.70^{a}$ & $8.3 \pm 0.67^{\mathrm{a}}$ & $8.2 \pm 0.63^{a}$ & $8.1 \pm 0.57^{a}$ \\
\hline Flavour & $8.8 \pm 0.42^{a}$ & $8.8 \pm 0.42^{\mathrm{a}}$ & $8.6 \pm 0.52^{a}$ & $8.4 \pm 0.70^{\mathrm{a}}$ & $8.3 \pm 0.82^{a}$ & $8.2 \pm 0.79^{a}$ & $8.1 \pm 0.74^{\mathrm{a}}$ \\
\hline Texture & $8.5 \pm 0.53^{\mathrm{a}}$ & $8.4 \pm 0.52^{\mathrm{a}}$ & $8.2 \pm 0.42^{\mathrm{a}}$ & $8.1 \pm 0.32^{\mathrm{a}}$ & $8.1 \pm 0.32^{\mathrm{a}}$ & $8.0 \pm 0.47^{\mathrm{a}}$ & $8.0 \pm 0.47^{\mathrm{a}}$ \\
\hline Taste & $8.7 \pm 0.48^{a}$ & $8.5 \pm 0.53^{\mathrm{a}}$ & $8.4 \pm 0.52^{a}$ & $8.3 \pm 0.48^{a}$ & $8.2 \pm 0.42^{\mathrm{a}}$ & $8.1 \pm 0.32^{\mathrm{a}}$ & $8.1 \pm 0.32^{a}$ \\
\hline $\begin{array}{l}\text { Overall } \\
\text { appearance }\end{array}$ & $8.7 \pm 0.48^{\mathrm{a}}$ & $8.6 \pm 0.52^{a}$ & $8.5 \pm 0.53^{a}$ & $8.4 \pm 0.70^{\mathrm{a}}$ & $8.2 \pm 0.63^{\mathrm{a}}$ & $8.1 \pm 0.57^{\mathrm{a}}$ & $8.0 \pm 0.47^{\mathrm{a}}$ \\
\hline Remarks & $\begin{array}{l}\text { Bright } \\
\text { green } \\
\text { colour, } \\
\text { good } \\
\text { flavour } \\
\text { and taste }\end{array}$ & $\begin{array}{l}\text { Bright green } \\
\text { colour, good } \\
\text { flavour and } \\
\text { taste }\end{array}$ & $\begin{array}{l}\text { Bright } \\
\text { green } \\
\text { colour, } \\
\text { good } \\
\text { flavour } \\
\text { and taste }\end{array}$ & $\begin{array}{l}\text { Bright green } \\
\text { colour, good } \\
\text { flavour and } \\
\text { taste }\end{array}$ & $\begin{array}{l}\text { Bright green } \\
\text { colour, good } \\
\text { flavour and } \\
\text { taste }\end{array}$ & $\begin{array}{l}\text { Bright green } \\
\text { colour, good } \\
\text { flavour and } \\
\text { taste }\end{array}$ & $\begin{array}{l}\text { Bright green } \\
\text { colour, good } \\
\text { flavour and taste }\end{array}$ \\
\hline
\end{tabular}

Similar superscripts indicate non-significant difference at $\mathrm{p}>0.05$; Values are average \pm S.D. 
Table 9 . Colour measurement of Curry leaf chutney using Lovibond Tintometer during ambient temperature $\left(15-35^{\circ} \mathrm{C}\right)$ storage for 90 days $(n=3)$

\begin{tabular}{|l|l|l|l|c|c|c|c|c|}
\hline $\begin{array}{l}\text { Packaging } \\
\text { material/storage } \\
\text { days }\end{array}$ & R/Y/B & 0 day & $\begin{array}{l}\mathbf{1 5} \\
\text { day }\end{array}$ & $\mathbf{3 0}$ day & $\mathbf{4 5}$ day & 60 day & 75 day & 90 day \\
\hline \multirow{3}{*}{ PET/Metpoly/PE } & $\mathrm{R}$ & 3.3 & 3.3 & 3.3 & 3.4 & 3.6 & 3.7 & 3.8 \\
\cline { 2 - 10 } & $\mathrm{Y}$ & 30 & 30 & 30 & 30 & 30 & 30 & 30 \\
\cline { 2 - 10 } & $\mathrm{B}$ & 7.0 & 7.0 & 7.0 & 7.0 & 7.0 & 7.0 & 7.0 \\
\hline
\end{tabular}

\subsubsection{Estimation of oxidative rancidity in} Curry leaf chutney stored under ambient temperature $\left(15-35^{\circ} \mathrm{C}\right)$ conditions

Curry leaf chutney had a crude fat content of $14.81 \%$. The raw materials such as sesame seeds are rich in unsaturated fatty acids (Toma and Tabekhia, 1979). Due to the unsaturated fat content, the product was exposed to the risk of development of oxidative rancidity. The TBA test was carried out on the samples of curry leaves chutney to estimate the extent of oxidative spoilage during the storage at ambient temperature conditions for 90 days. The absorbance of the TBA reactive substances (TBARS) in the sample was measured at 530nm. The changes in absorbance for the curry leaf chutney packed in PET/Metpoly/PE and stored at ambient temperature conditions for 90 days have been shown in Table 10. The product showed non-significant, little change in absorbance from 1.01 to 1.06 . Also as seen from Table 8, there was no off flavor developed during the storage period of 90 days, indicating very small/no development of rancidity in the sample. The PET/Metpoly/PE packaging material had good oxygen barrier properties, preventing the oxidative spoilage for more than the storage period of 90 days. Capriles et al., (2009) studied the use of rapeseed oil as a replacement for partially hydrogenated vegetable oil in snack flavoring and observed that low TBARS values and absence of offflavours indicate that lipid oxidation did not progress significantly during the storage period.

Table 10. Changes in absorbance at 530nm in Curry leaf chutney stored under ambient temperature $\left(15-35^{\circ} \mathrm{C}\right)$ conditions for 90 days $(\mathrm{n}=3)$

\begin{tabular}{|c|c|c|c|c|c|c|c|}
\hline $\begin{array}{c}\text { Packaging } \\
\text { material/storage } \\
\text { days }\end{array}$ & 0day & $\mathbf{1 5}$ day & $\mathbf{3 0}$ day & $\mathbf{4 5}$ day & $\mathbf{6 0}$ day & $\mathbf{7 5}$ day & $\mathbf{9 0}$ day \\
\hline PET/Metpoly/PE & 1.01 & 1.01 & 1.02 & 1.03 & 1.05 & 1.06 & 1.06 \\
\hline
\end{tabular}

Values are average of triplicates

\subsubsection{Microbiological analysis of Curry leaf chutney stored under ambient temperature $\left(15-35^{\circ} \mathrm{C}\right)$ conditions \\ Microbiological analysis of curry leaf chutney packaged in PET/Metpoly/PE carried out at 15 day intervals for 90 days of storage period in triplicates is presented in Table 11. No microbial growth was found on 0 day in samples packed in both the packaging materials.}

However, at the end of storage period, i.e. 90 day, samples showed growth of aerobic microorganisms as well as yeast $\&$ mold. The samples packed in PET/Metpoly/PE laminated pouches had ACC- $2.5 \times 10^{3} \mathrm{cfu} / \mathrm{ml} \& \mathrm{YMC}-2.3$ $\mathrm{x} 10^{3} \mathrm{cfu} / \mathrm{ml}$. An increase in the rate of growth of ACC was observed after 75 days of storage in PET/Metpoly /PE samples. 
Table 11. Microbiological analysis of Curry leaf chutney stored under ambient temperature $\left(15-35^{\circ} \mathrm{C}\right)$ conditions $(n=3)$

\begin{tabular}{|c|c|c|c|c|c|c|c|c|}
\hline $\begin{array}{c}\text { Packaging } \\
\text { material/stora } \\
\text { ge days } \\
\end{array}$ & Parameter & 0 day & 15 day & 30 day & 45 day & $\begin{array}{c}60 \\
\text { day }\end{array}$ & 75 day & 90 day \\
\hline \multirow{2}{*}{$\begin{array}{l}\text { PET/Metpoly/ } \\
\text { PE }\end{array}$} & $\begin{array}{l}\text { Aerobic } \\
\text { colony } \\
\text { count } \\
(\mathrm{ACC}) \\
(\mathrm{cfu} / \mathrm{ml}) \\
\end{array}$ & $\begin{array}{l}\text { No } \\
\text { growth }\end{array}$ & $\begin{array}{l}4.5 \mathrm{x} \\
10^{1}\end{array}$ & $\begin{array}{c}1.4 \mathrm{x} \\
10^{2}\end{array}$ & $\begin{array}{c}3.2 \mathrm{x} \\
10^{2}\end{array}$ & $\begin{array}{l}5.6 \mathrm{x} \\
10^{2}\end{array}$ & $\begin{array}{c}9.1 \mathrm{x} \\
10^{2}\end{array}$ & $\begin{array}{c}2.5 \mathrm{x} \\
10^{3}\end{array}$ \\
\hline & $\begin{array}{l}\text { Yeast \& } \\
\text { Mold } \\
\text { count } \\
(\text { YMC)( } \\
\text { cfu/ml) }\end{array}$ & $\begin{array}{l}\text { No } \\
\text { growth }\end{array}$ & $\begin{array}{c}1.0 \mathrm{x} \\
10^{1}\end{array}$ & $\begin{array}{c}4.1 \mathrm{x} \\
10^{1}\end{array}$ & $\begin{array}{c}1.2 \mathrm{x} \\
10^{2}\end{array}$ & $\begin{array}{l}4.6 \mathrm{x} \\
10^{2}\end{array}$ & $\begin{array}{c}\text { 7.4.x } \\
10^{2}\end{array}$ & $\begin{array}{c}2.3 \mathrm{x} \\
10^{3}\end{array}$ \\
\hline
\end{tabular}

\section{Conclusions}

Curry leaf chutney is a popular food adjunct in Indian cuisine. The product was standardized with dried and roasted curry leaves (10\%), Bengal gram (40\%), Black gram (20\%) and spice mix (30\%). It was rich in nutrients and can be used as a functional food adjunct. The storage studies conducted in PET/Metpoly/PE pouches under ambient temperature $\left(15-35^{\circ} \mathrm{C}\right)$ conditions revealed that the standardized Curry leaf chutney when packaged in suitable packaging material was shelf stable for more than 90 days. Curry leaf has medicinal, nutritional properties and are also used as flavouring agent. Use of it and other functional ingredients in food adjuncts can help in transferring the benefits to the diverse population.

\section{References}

Amerine, M.A., Pangborn, R.M. and Roessler, E.B.(1965). In: Principles of Sensory Evaluation of Food, Academic Press, New York.

Atwater, W.O. and Benedict, F.G. (1902). An experimental enquiry regarding the nutritive value of alcohol, Memoirs of the National Academy of Sciences, 8, 231-397.

Bacteriological Analytical Manual. (2001). Available online Accessed on $1^{\text {st }}$ January, 2015.

Capriles, V.D., Soares, R.A.M. and Areas, J.A.G. (2009). Storage stability of snacks with reduced saturated and trans fatty acids contents, Ciência e Tecnologia de Alimentos, Campinas, July-Sept., 29(3), 690-695

Deshmukh, S.K., Jain, P.C. and Agarwal, S.C. (1986). Anti-microbial activity of the leaves of essential oil of Murraya koenigii (Linn.) Spreng (Indian Curry Leaf), Fitoterapia, 57, 295-297.

Ganesan, P., Phaiphan, A., Murugan, Y.and Baharin, B.S. (2013). Comparative study of bioactive compounds in curry and coriander leaves:An update, Journal of Chemical and Pharmaceutical Research, 5(11), 590-594.

Gopalan, C., Rama Sastri, B.V. and Balasubramanian, S. (2014). In : Nutritive Value of Indian Foods, National Institute of Nutrition (NIN), ICMR.

Joseph, S. and Peter, K.V. (1985). Curry leaf (Murraya koenigii), perennial nutritious leafy vegetable, Econ Bot, 39, 68-73.

Khedkar, R., Shastri, P. and Bawa, A. S.. (2016). Standardization, characterization and shelf life studies on Sandge, a traditional food adjunct of western India, International Journal of Environment, Agriculture and Biotechnology (IJEAB), Vol.1, issue 2, JulyAugust, 237-243

Khedkar, R., Shastri, P. and Bawa, A. S. (2016). Standardization, chemical characterization and storage studies on Metkut, a pulse based Indian Traditional Food Adjunct, Food 
Science Research Journal (ISSN: 09761276), April, vol.7, issue 1, 105-111.

Khedkar, R. 2015. Curry Leaf (Murraya koenigii L. Spreng) as a functional food: A review. Food Science Research Journal, Vol.6, Issue 1, 135-141.

Kinsella, J.F. and Fox, P.F.,Water sorption by milk proteins, Bulletin of the International Dairy Federation, 209, 12-40, 1987.

Landrock, A.H. and Proctor, B.E..(1951). Mod Packag,24(6), 123.

Mathias, M.E.(1994). Magic, Myth and Medicine, Economic Botany, 48, 3-7.

Meilgaard, M., Civille G.V. and Carr B.T. (1999). In: Sensory evaluation techniques, $3^{\text {rd }}$ edition, CRC, Boca Raton.

Pathak, N., Yadav, T.D., Jha, A.N. and Vasudevan, P. (1997). Contact and fumigant action of volatile essential oil of the leaves of Murraya koenigii against Callosobruchus chinensis, Indian Journal of Entomology, 59, 198-202.

Punna, R. and Rao Paruchuri, U.( 2004). Effect of maturity and processing on total, insoluble and soluble dietary fiber contents of Indian green leafy vegetables, International Journal of Food Sciences and Nutrition, 55(7), 561-7.

Ramalakshmi, K., Rao, L.J.M. and Sulochanamma, G. (2000). Physicochemical changes on processing of curry leaf (Murraya koenigii Spreng.), Journal of Medicinal and Aromatic and Plant Sciences, 22, 510-516.

Ranganna, R. (2001). In: Handbook of Analysis and Quality control for fruit and Vegetable products, $2^{\text {nd }}$ edition, Tata McGraw Hill, New Delhi.

Rao, D.G., Jyothirmayi, T., Prabhakar Rao, P.G. and Narsing Rao, G. (2008). Chemical composition, standardization and storage studies on raw mango chutney powder, Journal of Food Science and Technology, 45(5), 436-438.

Rao, D.G., Balaswamy, K. and Jyothirmayi, T. (2004). Studies on Preparation of Curry Leaf (Murraya koenigii L.) Chutney Powder, Foodservice Research International, 14,175187.
Satyanarayana, A., Giridhar, N., Balaswamy, K., Shivaswamy, R. and Rao, D.G..( 2001). Studies on development of instant chutneys from Pudina (Mint, Mentha spicata) and Gongura (Hibiscus sp.), Journal of Food Science and Technology, 38(5), 512.

Satyanarayana, A., Balaswamy, K., Mala, K.S., Narsing Rao, G. and Rao, P.P. (2013). Preparation and storage stability of flaxseed chutney powder, a functional food adjunct Journal of Food Science and Technology, 50(1), 129-134.

Shastri, P. N. (2006). Changing face of traditional food adjuncts, Indian Food Industry, 25(6), 73-77.

Singh, S., Omre, P.K. and Mohan, S.M. (2014). Curry leaves (Murraya koenigii Linn Sprengal)- Miracle Plant, Indian Journal of Scientific Research(IJSR), 4(1), 46-52.

Smith, A.C. (1985). In: Flora vitiensis nova: A new flora of Fiji (Spermatophytes only), Lavai, Kuwai, Hawaii: Pacific Tropical Botanic Garden, 3, 758.

Tapsell, L.C., Hemphill, I. and Cobiac, L.,Patch, C.S., Sullivan, D.R. et al..(2006). Health benefits of herbs and spices: The past, the present, the future, The Medical Journal of Australia, 185, S4-24.

The Wealth of India, Raw materials series. (2001). Vol. VI, NISCAIR, CSIR, New Delhi, India, 446.

Toma, R.B., Tabekhia, M.M. (1979). Phytate and oxalate contents in sesame seed, Nutrition Reports, 20, 25-31. 